$$
634.616: 6.11 .8
$$

\title{
Goat Manure as a Soil Ameliorant and Yield 'Stimulant' In Coconut
}

\author{
N. A. TENNAKOON \\ Coconut Research Institute, Lunuwila Sri Lanka
}

\begin{abstract}
Studies were carried out on a seven-year-old dwarf $x$ tall (CRIC 65) hybrid coconut to evaluate the usefulness of goat manure as a source of nutrients and as a soil ameliorant.

Goat manure caused significant increase in nut yield (35.2\%), copra weight $(40.3 \%)$, nuts/bunch (20.5\%) and female flowers/tree (15.5\%) during the third year of experimentation. The increases for copra weight, nut weight, female flowers/bunch and number of bunches/tree ranged from $6.1 \%$ to $10.1 \%$ but were not significant.

Goat manure also improved soil microbiological activity, organic matter content and water holding capacity. The results showed that goat manure has much scope as an organic fertilizer and as a soil ameliorant in coconut cultivation.
\end{abstract}

\section{INTRODUCTION}

The national demand for coconut and coconut products has increased steadily with increasing population and rising living standards. However, the extent of coconut in Sri Lanka is gradually declining as a result of urbanisation, road development, power distribution, industrialisation, construction of houses etc. In the long term, this situation could be overcome to some extent by using improved planting material and by adopting better cultivation methods. A short-term strategy for increasing production is through increased use of fertilizer, be it chemical or organic.

Generally, the fertility of coconut soils in Sri Lanka is poor, due to the continuous removal of soil nutrients by palm products such as fruits (drupes), husks, shell, sap, falling fronds etc. The soil nutrients are normally replenished by the use of chemical fertilizers. In the recent past, scientists and laymen have expressed concern on the dangers of indiscriminate and/or continuous use of chemical fertilizer in the soil as it eventually reduces the soil biological activity (Soderstrom et al., 1983). It is also a known fact that chemical fertilizer have no secondary role other than as a source of concentrated nutrients.

These expressed views and findings have led to studies on the use and role of organic fertilizers used alone or in combination with chemical fertilizers. Organic fertilizer, while providing limited amounts of nutrients, has a secondary role towards enhancing soil 
microbiological activity and as a soil ameliorant in improving cation exchange capacity (CEC), water holding capacity and other physical properties of the soil (Shantaram et al., 1973; Joshi et al., 1982; Pera et al., 1983). Its use appears to be beneficial in coconut plantations in lateritic and sandy soils which have low CEC and poor physical properties. This paper discusses the results of experiments conducted to study the role of goat manure as a supplement to chemical fertilizer in a coconut plantation.

\section{MATERIALS AND METHODS}

The experiment to study the response of coconut to application of goat manure along with chemical fertilizer was carried out at the main experimental station of the Coconut Research Institute, Lunuwila, Sri Lanka located in North-Western Province (latitude $7^{\circ} \mathrm{N}$; altitude 100 $\mathrm{m} \mathrm{MSL).} \mathrm{The} \mathrm{physical} \mathrm{and} \mathrm{chemical} \mathrm{properties} \mathrm{of} \mathrm{the} \mathrm{soil} \mathrm{at} \mathrm{the} \mathrm{commencement} \mathrm{of} \mathrm{the}$ experiment were as follows:

Particles distribution: Sand $93.25 \%$, Silt $1.65 \%$, Clay $5.10 \%$

$\begin{array}{lll}\begin{array}{l}\text { Soil Colour } \\ \quad \text { Greyish Brown }\end{array} & : & 10 \text { YR 5/2(wet) } \\ \quad \text { Pale Brown } & : & 10 \text { YR 6/3 (dry) } \\ \text { Available water } & : & 0.90 \% \\ \text { pH } & : & 6.3 \\ \text { Organic matter } & : & 0.35 \% \\ \text { Cation exchange capacity } & : & 4.8 \mathrm{meq} / 100 \mathrm{~g} \text { soil }\end{array}$

The rainfall distribution during the experimental period is given in Table 1.

Table 1 - Rainfall (mm) Distribution

\begin{tabular}{|c|c|c|c|c|c|}
\hline \multirow[t]{2}{*}{ Month } & \multicolumn{5}{|c|}{ Year } \\
\hline & 1983 & 1984 & 1985 & 1986 & 1987 \\
\hline January & 0 & 197 & 13 & 61 & 31 \\
\hline February & 0 & 107 & 189 & 35 & 0 \\
\hline March & 0 & 145 & 228 & 62 & 118 \\
\hline April & 219 & 425 & 103 & 60 & 237 \\
\hline May & 322 & 297 & 275 & 284 & 187 \\
\hline June & 138 & 115 & 291 & 44 & 61 \\
\hline July & 79 & 111 & 14 & 33 & 6 \\
\hline August & 120 & 0 & 139 & 77 & 156 \\
\hline September & 242 & 129 & 168 & 94 & 410 \\
\hline October & 50 & 121 & 195 & 224 & 579 \\
\hline November & 159 & 239 & 306 & 149 & 194 \\
\hline December & 141 & 83 & 63 & 63 & 79 \\
\hline Total & 1479 & 1969 & 1984 & 1186 & 2058 \\
\hline
\end{tabular}


The coconut palms used for the experiment were seven-year-old, high-yielding dwarf $\mathrm{x}$ tall variety, CRIC 65 . These palms had been originally used for a different experiment during the seedling stage where only chemical fertilizer was applied to study the initial growth performance. However, by the time the present experiment commenced, the palms had not shown any significant response to the different treatments, thus providing suitable material for further experimentation. The initial design used was a randomized block design with three replicates. The new experiment was incorporated into the old experiment where each plot was divided into two plots making a split-plot arrangement.

The treatments applied to the two split-plots were (1) $4.5 \mathrm{~kg}$ of chemical coconut fertilizer mixture per palm year (2) $4.5 \mathrm{~kg}$ chemical coconut fertilizer mixture and $20 \mathrm{~kg}$ goat manure per palm per year. The chemical coconut fertilizer mixture consisted of 10.5 parts urea $(46 \%$ $\mathrm{N}), 10.5$ parts of saphosphosphate $\left(27.5 \% \mathrm{P}_{2} \mathrm{Os}\right)$ and 24 parts of muriate of potash $\left(60 \% \mathrm{~K}_{2} \mathrm{O}\right)$ by weight. The addition of $20 \mathrm{~kg}$ of goat manure is equivalent to the application of $1.1 \mathrm{~kg}$ urea, $0.4 \mathrm{~kg}$ saphosphosphate, $0.4 \mathrm{~kg}$ muriate of potash and $1.3 \mathrm{~kg}$ dolomite. These fertilizers were applied annually.

The experiment commenced in 1983 and the yield data were recorded bimonthly. The parameters recorded in 1987 were used in this presentation. These were: (1) number of matured nuts per bunch, (2) total number of female flowers per bunch, (3) number of bunches per tree, and (4) weight of the matured husked nuts per tree. The copra weight was calculated by multiplying the weight of husked nuts by a conversion factor of 0.32 .

Varying levels of goat manure supplemented with chemical fertilizer (to equate with chemical coconut mixture, nutrient-wise) in a secondary form were tested for available water content in sandy soil. The available water in soil was estimated by the difference between $1 / 3$ bars and 15 bars using the pressure plate apparatus.

The microbial activity in the soil due to application of different levels of goat manure supplemented with chemical fertilizers was also studied. Out of a large number of relevant parameters, only the following are discussed in this paper: (1) number of total bacterial colonies (Dilution plate technique) (Parkinson et al., 1971) (2) number of total fungal colonies (Dilution plate technique) (Parkinson et al., 1971) (3) total microbial biomass C (Fumigation method) (Parkinson \& Paul, 1982), and (4) microbial respiration (static method) (Kibble, 1966).

\section{RESULTS AND DISCUSSION}

\section{Goat dung as a yield stimulant}

The yield data and the differences in yield between treatments of the first experiment are given in Table 2.

In the case of goat manure supplementation treatment, the two most important yield parameters, namely the number of nuts and weight of copra per palm per year showed increases of $35.2 \%$ and $40.3 \%$ respectively over the application of chemical fertilizer and were highly significant $(P=0.001)$. The number of nuts per bunch and the total number of female 
Table 2 - Effect of Chemical Fertilizer and Goat Manure on yield parameters and soil organic matter content

\begin{tabular}{|c|c|c|c|c|c|c|}
\hline Parameter & $\begin{array}{c}\text { Chemical } \\
\text { fertilizer } \\
(4.5 \mathrm{~kg})\end{array}$ & 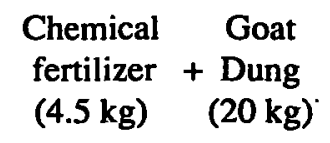 & $\begin{array}{c}\% \\
\text { Increase }\end{array}$ & Significance & CV\% & $\begin{array}{l}\text { SE } \\
(\mathrm{X})\end{array}$ \\
\hline No. of nuts / tree / yr & 33.3 & 44.9 & 35.2 & $\cdots$ & 19.8 & 1.49 \\
\hline Wt. of Copra / tree / yr (kg) & 6.7 & 9.4 & 40.3 & $* *$ & 24.2 & 0.38 \\
\hline No. of nuts / bunch & 4.4 & 5.3 & 20.5 & * & 27.5 & 0.26 \\
\hline Total FF / tree & 130.9 & 151.3 & 15.6 & • & 23.9 & 6.50 \\
\hline Copra / nut (g) & 201.8 & 209.3 & 3.7 & NS & 18.1 & 0.02 \\
\hline FF/ Bunch & 16.0 & 17.3 & 8.1 & NS & 21.2 & 0.68 \\
\hline No. of bunches / palm / yr & 7.9 & 8.7 & 10.1 & NS & 17.8 & 0.28 \\
\hline $\begin{array}{l}\text { Organic matter (\%) } \\
\text { (after } 12 \text { months) }\end{array}$ & 1.22 & 1.77 & 45.0 & $\cdots$ & 8.2 & 0.07 \\
\hline
\end{tabular}

$* \mathrm{P}=0.05 \quad * * * \mathrm{P}=0.001 ; \mathrm{NS}=$ Not Significant

$* * \mathrm{P}=0.01 ; \quad \mathrm{FF}=$ Female flowers 


\section{N. A. TENNEKOON}

flowers per palm were also significantly higher in the goat manure supplementation treatment compared to only chemical fertilizer. The increases were 20.5 and $15.6 \%$ respectively. There were no significant differences for copra weight per nut, female flowers per bunch and the number of bunches per palm, although increases ranging from $6.1 \%$ to $10.1 \%$ were evident. These parameters generally have a lower variation, but the practical value of even a marginal increase is important.

\section{Goat manure as a soil ameliorant}

The water holding capacity in the soil showed a significant linear increase with increase in the rate of application of goat manure (Fig. 1). These results suggest that goat manure plays a significant role in improving an important soil physical property, which will contribute directly to improving yields.

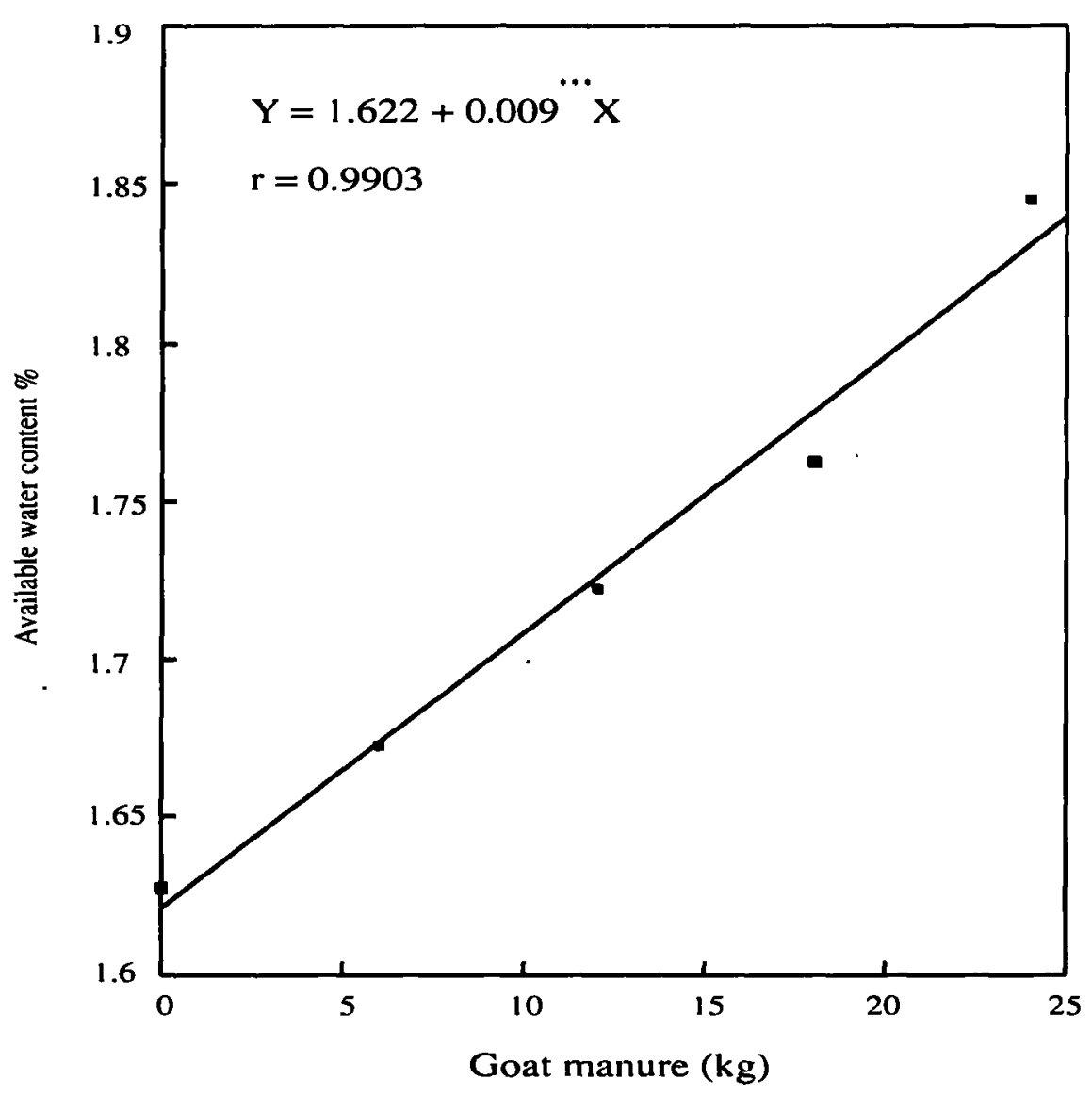

Fig 1 - Effect of increasing goat manure on water holding capacity of soil 
(a) bacteria

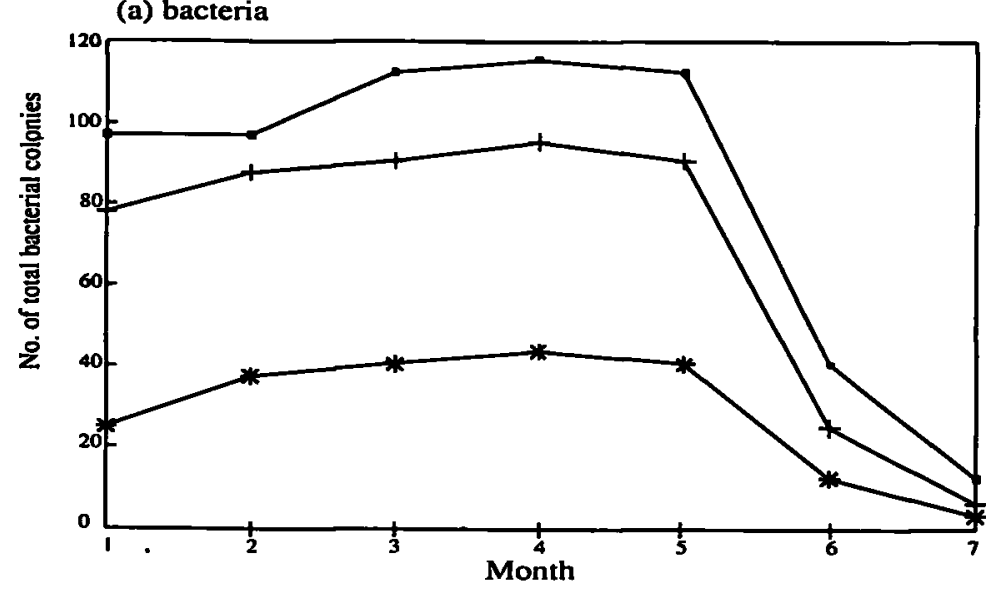

(c) biomass

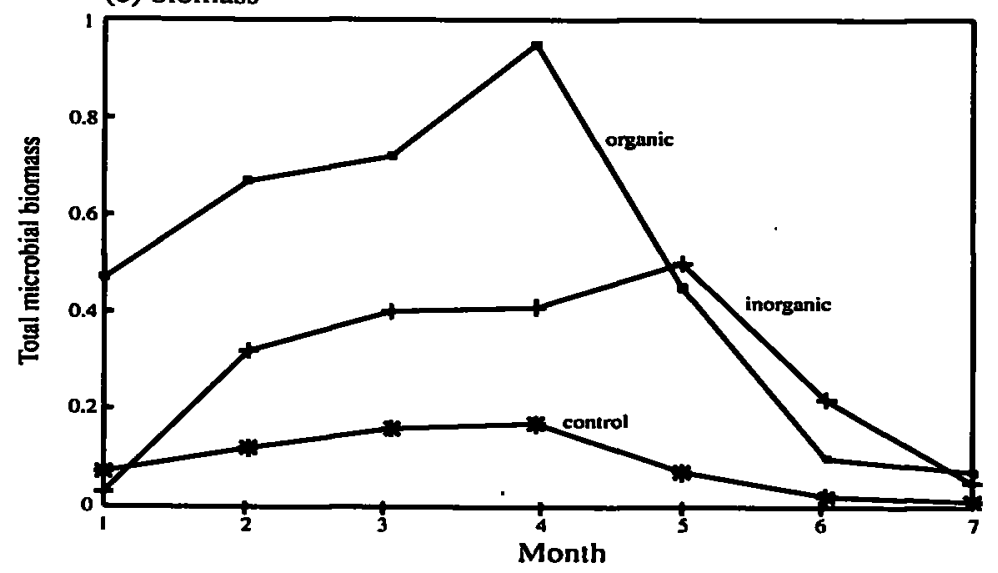

(b) fungi

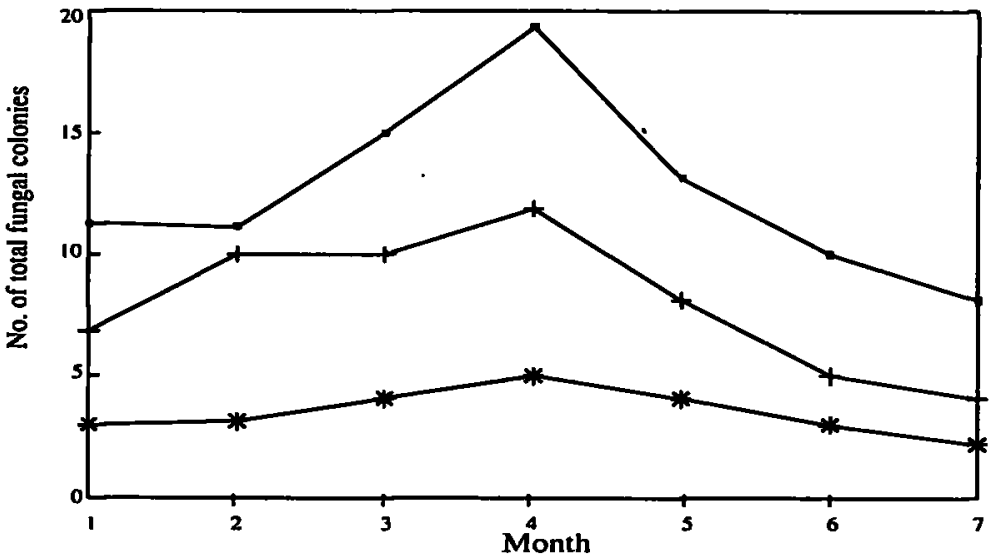

(d) $\mathrm{CO}_{2}$ evolution

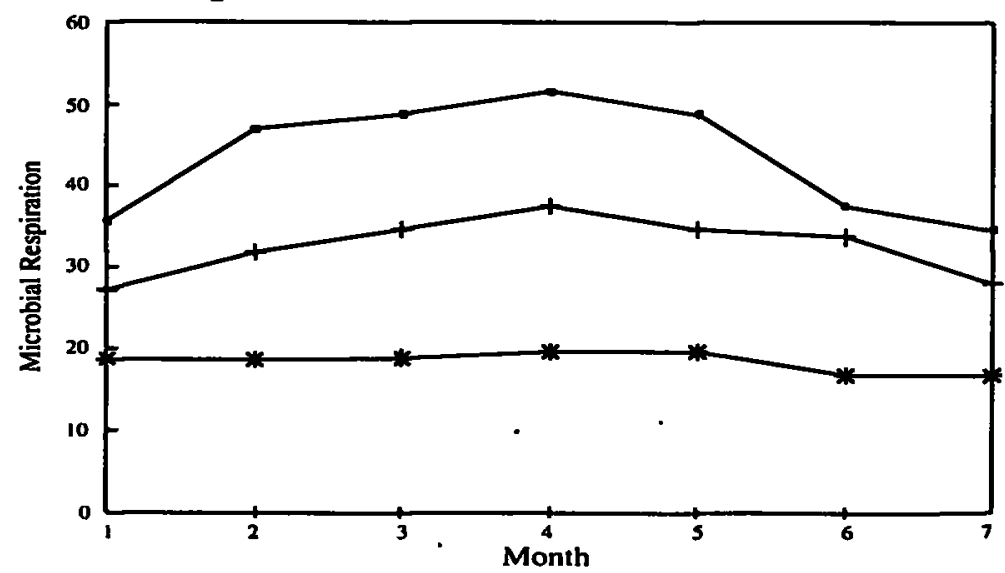

Fig.2 - Microbial activity in response to applied fertilizers

( organic; + inorganic; * control) 
The number of total bacterial colonies, total fungal colonies, microbial biomass $\mathrm{C}$ and microbial respiration showed a marked increase for both goat manure and only chemical fertilizer-treated plots over the control up to the fourth month after fertilizer application. Goat manure-treated plots showed the highest microbial population and activity for all the four parameters followed by chemical fertilizer-treated plot. (Figs. 2 a, 2 b, 2 c, 2 d).

The organic matter content in plots treated with goat manure at the end of 12 th month was found to be $45 \%$ more than in plots treated with chemical fertilizer (Table 2). The overall increase in soil microbial activity in plots treated with goat manure over the rest can be attributed to the high organic matter content. This increase in soil microbial activity enhances the decomposition of organic sources in the soil, thereby increasing the soil humus content which in turn enhances both physical and chemical properties of the soil.

These experiments show that goat manure not only supplies plant nutrients to the soil but also plays a significant role in improving the water-holding capacity of the soil, which is an important soil physical property and also enhances soil microbial activity thereby ameliorating the soil. These results show that goat manure has much scope as a nutrient source and as a soil ameliorant in coconut cultivation and its importance in improving poor coconut soils.

\section{REFERENCES}

Joshi O. P., Nambiar C. K. B. and Khan H. H. (1982). Effect of organic manuring on some physical properties and water retention of coastal sand. Philip. J. Cocon. Stud. 7(1-2); 42-46.

Kibble R. A. (1966). Physiological activity in a pinerood soil. In 1 B P Handbook, International Biological Programme, London.

Parkinson D. and Paul A. E. (1982). Microbial biomass. In Methods of soil Analysis, Part 2 - Chemical \& Microbiological Properties. Agronomy Monograph No. 9; 821-830.

Parkinson D., Gray T. R. G. and Williams S. T. (1971) Methods for studying the ecology of soil. In I B P Handbook No. 19, International Biological Programme, London.

Pera A., Vallini G., Inessineno M., Bianchin L. and de Bertoldi M. (1983). Effect of organic matter on rhizosphere microorganisms and root development of sorghum plants in two different soils. Plant and Soil 74; 3-18.

Shantaram M. V., Balasubramanin A. and Ragaswami G. (1973). Sequence of soil microflora decomposing maize straw and stubble added to a red sandy loam soil. Madras Agric. J. 60 (8); 1074-1079.

Soderstrom B., Baath E. and Lundgren B. (1983). Decrease in soil microbial activity and biomass owing to $\mathrm{N}$ amendments. Can. J. Microbiol. 29; 1500-1506. 